\title{
Analisis Perkembangan Motorik Kasar Anak di Taman Kanak - Kanak Buton Selatan
}

\author{
Asmuddin $^{1}{ }^{\bowtie}$, Salwiah $^{2}$, Muh. Zaenal Arwih ${ }^{1}$ \\ Ilmu Keolahragaan, Universitas Halu Oleo, Indonesia(1) \\ Pendidikan Anak Usia Dini, Universitas Halu Oleo, Indonesia(2) \\ DOI: $10.31004 /$ obsesi.v6i4.2068
}

\begin{abstract}
Abstrak
Mempersiapkan anak untuk menghadapi kehidupan yang akan datang sangat diperlukan. Anak merupakan individu yang akan melanjutkan generasi manusia pada masa yang akan datang. Salah satu yang harus diperhatikan adalah perkembangan motorik kasarnya. Tujuan penelitian ini untuk mendeskripsikan perkembangan motorik kasar anak. Jenis penelitian ini adalah kualitatif deskriptif. Metode pengumpulan data yang digunakan yaitu observasi, wawancara dan dokumentasi. Hasil penelitian menunjukkan bahwa kegiatan pengembangan motorik kasar anak sudah terselenggara secara baik. Berdasarkan hasil analisis, dapat ditarik kesimpulan bahwa pengembangan motorik kasar anak usia dini dapat membantu pertumbuhan fisik pada anak, meningkatkan keseimbangan tubuh anak, melatih kelenturan, kecepatan, dan kelincahan, 4. melatih koordinasi mata, tangan, dan kaki, dan membantu perkembangan kemampuan melompat dengan satu kaki.
\end{abstract}

Kata kunci: analisis perkembangan; motorik kasar; anak usia dini

\begin{abstract}
Preparing children for the life to come is very necessary. Children are individuals who will continue human generations in the future. One thing that must be considered is the development of gross motor skills. The purpose of this research was to describe the children gross motor development. This type of research is descriptive qualitative. Data collection methods used are observation, interviews and documentation. The results showed that the children's gross motor development activities were well organized. Based on the results of the analysis, it can be concluded that the development of gross motor skills in early childhood can be help of physical growth to the children, improve the balance of the child's body, train of flexibility, speed, and agility, train of eye, hand, and foot coordination, and help of jumping development ability on one leg.
\end{abstract}

Keywords: analysis development; gross motor; early childhood

Copyright (c) 2022 Asmuddin, et al.

$\triangle$ Corresponding author :

Email Address : asmuddin@uho.ac.id (Kendari, Indonesia)

Received 25 November 2021, Accepted 18 February 2022, Published 27 February 2022 


\section{PENDAHULUAN}

Perkembangan fisik motorik merupakan hal yang sangat penting dikembangkan, karena memberikan pengaruh untuk perkembangan lainnya seperti perkembangan kognitif, sosial dan emosional (Aye et al., 2017), (Hernandez \& Cacola, 2015), (Piek et al., 2008). Pendidikan usia dini adalah periode penting yang perlu mendapat perhatian dan penanganan sedini mungkin. Salahsatu kemampuan anak yang sedang berkembang saat usia dini yaitu kemampuan motorik. Usia 3-6 tahun merupakan emas pada anak, yang memerlukan stimulus untuk membantu perkembangannya sehingga tidak terhambat. Aspek perkembangan anak dapat berkembang dengan baik apabila mendapat stimulas yang baik. Masa ini adalah masa emas (Golden Age) dalam mengembangkan kemampuan fisik, kognitif, bahasa, sosial, emosional, konsep diri, disiplin, kemandirian anak. Anak usia dini adalah manusia yang polos serta memiliki potensi yang masih harus dikembangkan. Anak usia dini adalah anak yang masuk pada rentang usia 0-6 tahun. Sesuai dengan pasal 28 (Undang-Undang No. 20, 2003) Sistem Pendidikan Nasional No. 20/2003 ayat 1 yang menyatakan bahwa anak usia dini adalah anak yang masuk pada rentang usia 0-6 tahun.

Perkembangan keterampilan motorik kasar anak yang paling pesat pada saat usia prasekolah, sekolah dasar dan mampu menguasai keterampilan motorik kasar lebih baik pada periode ini dari pada pada usia setelahnya dalam hidup mereka (Olrich, 2013). Maka dari itu kemampuan motorik kasar perlu dikembangkan sejak usia dini. Perkembangan kemampuan motorik pada anak membutuhkan aktivitas fisik untuk pertumbuhan dan perkembangannya (Ailwood, 2003). Bentuk kegiatan bermain haruslah memacu otot-otot pada anak. Melalui permainan sebagai sarana bagi anak untuk menjelajahi dunianya, mulai dari yang tidak diketahuinya hingga apa yang diketahui oleh anak dan anak dapat membangun pengalamannya. Permainan merupakan alat pendidikan karena dapat memberi kebahafiaan, kegembiraan dan kepuasan (Theobald et al., 2015) melalui permainan anak mendapatkan manfaat untuk perkembangan fisik motorik dan sosial emosionalnya.

Aktivitas yang dilakukan oleh anak melalui bermain yang seharusnya tidak hanya menjadi aktivitas fisik biasa, tetapi dapat menjadi sarana belajar yang menyenangkan dan berolahraga secara tidak langsung. Melalui bermain yang dilakukan oleh anak diharapkan untuk memainkan permainan yang bermanfaat dari kekuatan otot dan fisik, keterampilan komunikasi, sosialisasi, sehingga dapat menyehatkan anak (Maidelwita, 2012). Bermain pada anak dapat dilakukan dengan aktivitas fisik seperti olahraga, permainan, dan kegiatan rekreasi yang dapat mengembangkan motorik kasar pada anak usia dini (Okely et al., 2004).

Perkembangan anak usia dini di Indonesia, diatur dalam (Permendikbud No. 137, 2014) No. 137 tentang Standar Nasional PAUD, di samping beberapa kebijakan lain yang mendukungnya. UU No. 20 tahun 2003 Pasal 1 butir 14 disebutkan bahwa pendidikan anak usia dini merupakan suatu upaya pembinaan yang ditujukan kepada anak sejak lahir sampai dengan usia enam tahun melalui pemberian rangsangan atau stimulus pendidikan untuk membantu pertumbuhan dan perkembangan jasmani dan rohani agar anak memiliki kesiapan dalam memasuki pendidikan lebih lanjut.

Pendidikan anak usia dini pada hakikatnya adalah pendidikan yang diselenggarakan dengan tujuana untuk memfasilitasi pertumbuhan dan perkembangan anak secara menyeluruh atau menekankan pada seluruh pengembangan aspek kepribadian anak (Suyadi, 2013: 17). Anak usia dini merupakan usia yang berada pada masa golden age, karena pada fase ini mereka sedang mengeksplor aktivitasnya dengan bergerak secara bebas sehingga dapat teroptimal seluruh aspek perkembangan anak usia dini. Motorik adalah perkembangan pengendalian gerakan tubuh melalui kegiatan yang terkoordinasi antara susunan saraf, otot dan otak. Motorik sendiri terdiri dari motorik kasar yang menggunakan otot-otot besar. Pada aspek motorik perkembangannya akan berjalan sesuai dengan tahapan usia. Saat ini kemampuan motorik anak mengalami perkembangan. 
Perkembangan motorik setiap anak berbeda, karena dipengaruhi oleh otak yang yang berfungsi untuk menyetir setiap gerakan anak. Dengan bertambahnya usia akan memungkinkan kemampuan motorik anak akan berkembang. Pada usia 3-6 tahun merupakan periode penting dalam tumbuh kembang anak terutama pada aspek perkembangan motorik. Kemampuan motorik anak usia 3-6 tahun yaitu mampu menggambar dengan krayon, menggunakan alat atau benda, dan dapat meniru bentuk (Susanto, 2010). Tujuan penelitian ini adalah untuk mendeskripsikan perkembangan kemampuan motorik anak usia 3-6 tahun. Perkembangan motorik anak usia 3-4 tahun pada umumnya memiliki kekuatan fisik yang mulai berkembang, seringkali bergerak bebas dengan berpindah-pindah tempat satu ke tempat lainnya.

Perkembangan ini akan lebih optimal apabila lingkungan sekitar rumah dapat menstimulasi dengan baik. Pada saat ini, tidak banyak orang tua yang memperhatikan perkembangan motorik anaknya. Orang tua belum mengerti bahwa keterampilan motorik kasar perlu dilatih pada setiap aktivitas yang anak lakukan. Untuk itu orang tua harus mampu mengenali pertumbuhan dan perkembangan anak sejak dini. Jika orang tua dapat mengawal setiap kegiatan anak untuk bergerak bebas maka perkembangan kemampuan motorik anak akan lebih teroptimalkan sehingga terhindar dari terjadinya keterlambatan perkembangan.

Perkembangan motorik merupakan salah satu factor yang sangat penting. Untuk mengembangkan kemampuan motorik yaitu orang tua memberikan dukungan untuk mengasah motorik anak dengan memberikan kesempatan pada anak untuk dapat bereksplorasi dengan lingkungan sekitar rumahnya. Anak diberikan fasilitas atau sarana prasarana yang dapat mendorong anak untuk bergerak bebas. Karena saat ini orang tua sekali membiarkan anak bermain gadget tanpa dibatasi waktnya. Hal itu menyebabkan anak menjadi duduk diam saja di rumah dengan menonton video sehingga akan berdampak pada kemampuan motorik anaknya mengalami keterlambatan. Banyak faktor yang dapat mempengaruhi perkembangan motorik anak khususnya pada usia 3-6 tahun. Pada usia tersebut merupakan masa dimana anak senang bereksplorasi. Anak masih suka bermain, melakukan aktivitas gerak secara bebas tanpa berhenti.

Perkembangan fisik motorik adalah pengendalian gerak jasmani melalui kegiatan yang berhubungan dengan urat saraf, pusat saraf, dan otot yang dapat dikoordinir. Aspek perkembangan fisik motorik merupakan hal mendasar bagi kemajuan perkembangan aspekaspek yang lainnya. Perkembangan ini berkembang seiring dengan kematangan otot dan syaraf pada tubuhnya, ditandai dengan penguasaan keterampilan motorik. Keterampilan motorik kasar adalah gerakan yang melibatkan otot besar. Keterampilan motorik kasar memerlukan beberapa unsur, diantaranya: kecepatan, kekuatan, ketahanan, kelincahan, fleksibilitas, koordinasi, dan keseimbangan (Erlinda, dkk, 2014).

Semakin berkualitas proses pertumbuhan dan perkembangan anak pada usia dini maka akan berpengaruh terhadap kualitas hidup manusia di masa mendatang. Anak-anak yang terlibat dalam aktivitas fisik, mereka memiliki kompetensi dasar dalam keterampilan motorik dasar, dan anak-anak belajar keterampilan dasar motorik melalui program gerakan yang dirancang dengan baik dan terencana (Robinson et al., 2012). Kurangnya keterampilan motorik kasar pada anak tentu akan menghambat mereka dalam aktivitas bersama teman sebaya. Anak dengan keterampilan motorik kasar buruk menunjukkan tingkat keaktifan yang lebih rendah dibandingkan anak yang keterampilan kasarnya berkembang dengan baik (Williams et al., 2008). Oleh karena itu, perlu dilakukan tindakan tertentu ketika pendidik menemukan indikasi keterampilan motorik kasar anak yang tidak sesuai dengan usianya.

Keterampilan motorik anak usia 3-6 tahun menurut indikator Standar Tingkat Pencapaian Perkembangan Anak, mencakup kemampuan anak untuk melakukan: 1) naikturun tangga atau tempat yang lebih tinggi dengan kaki bergantian; 2) berlari sambil membawa sesuatu yang ringan; 3) meniti di atas papan yang cukup lebar; 4) meniru gerakan 
senam sederhana seperti menirukan gerakan pohon, kelinci melompat; 5) melompat turun dari ketinggian kurang lebih $20 \mathrm{~cm}$ (di bawah tinggi lutut anak); dan 6) berdiri dengan satu kaki (Patiung et al., 2019). Keterampilan motorik kasar anak yang berhubungan dengan gerak lokomotor dan gerak koordinasi anak mencakup ketahanan, kecepatan, kelenturan, ketangkasan, keseimbangan, dan kekuatan. Memberikan kesempatan kepada anak untuk berlari, memanjat, menangkap, melempar, dan melompat akan mengembangkan keterampilan-keterampilan tersebut. Sehingga dengan stimulasi yang sesuai, anak diharapkan dapat menguasai keterampailan fisik motorik sesuai dengan indikator dalam STPPA.

Istilah keterampilan motorik menggambarkan berbagai kompetensi fisik, termasuk keseimbangan dan stabilitas, gerakan terkoordinasi, dan manipulasi objek. Perbedaan antara keterampilan motorik kasar dan halus dalam artikel L. Zhang et al. (2018), yakni keterampilan motorik kasar membutuhkan koordinasi otot-otot tubuh yang lebih besar dalam keseimbangan, postur, orientasi, dan pergerakan batang dan anggota badan sedangkan keterampilan motorik halus mengintegrasikan otot-otot yang lebih kecil untuk kegiatan seperti menggambar, menulis, membaca, dan berbicara dan biasanya termasuk ketangkasan manual dan integrasi visuomotor. Koordinasi dan kontrol untuk banyak jenis dan bentuk gerakan memiliki hubungan yang kompleks antara aktivitas fisik, keterampilan motorik halus dan motorik kasar yang dirasakan pada anak usia dini (Wainwright et al., 2020).

Kegiatan yang melibatkan banyak gerakan termasuk kegiatan bermain pada anak usia dini juga merupakan faktor penting dalam pengembangan kompetensi fisik, motorik karena periode usia dini merupakan waktu optimal untuk pengembangan keterampilan motorik yang berfungsi sebagai fondasi untuk aktivitas fisik yang lebih kompleks selanjutnya. Aktivitas fisik penting untuk berbagai aspek kesehatan dan perkembangan anak anak. Tandon et al. (2020), menjelaskan bahwa aktivitas fisik pada tahun-tahun awal anak usia dini mempromosikan pengembangan keterampilan motorik kasar dan gerakan mendasar, yang merupakan fondasi untuk membentuk kepercayaan diri dan keterampilan yang diperlukan anak untuk hidup yang aktif di kemudian hari.

Keterampilan motorik kasar dapat diperoleh anak secara alami melalui bermain, namun meskipun demikian banyak hal yang dapat menghambat proses alami ini terjadi tidak secara maksimal, hal ini mendukung argumen bahwa keterampilan motorik kasar perlu diajarkan kepada anak dan membutuhkan tingkat instruksi yang lebih tinggi untuk menguasai gerakan kompleks yang diperlukan untuk melakukan keterampilan motorik yang lebih kompleks dengan diberikan praktik dan latihan yang terarah. Lebih lanjut menurut Temple et al. (2016) dalam kajian teori perkembangannya menyebutkan bahwa aktifitas fisik yang terarah pada masa usia dini akan membantu memaksimalkan keterampilan motorik kasar anak.

\section{METODOLOGI}

Penelitian ini dilaksanakan pada kelompok anak di TK Nurhidayah Kelurahan Kadatua Kabupaten Buton Selatan. Pendekatan yang digunakan dalam penelitian ini adalah kualitatif deskriptif. Alasan yang mendasari penggunaan pendekatan kualitatif adalah untuk mendapatkan gambaran yang utuh guna memfokuskan pada proses penemuan makna dari fenomena yang ada pada subjek penelitian. Permasalahan yang hendak dipecahkan melalui rancangan ini adalah mendeskripsikan perkembangan motorik kasar anak TK, dan mengidentifikasi hambatan dalam implementasi perkembangan motorik kasar anak TK. Subjek penelitian adalah anak TK yang berusia 0-6 tahun. Teknik pengumpulan data dilakukan melalui wawancara mendalam, observasi, dan studi dokumentasi. Teknik analisis data dilakukan sebelum turun ke lapangan dan selama di lapangan dengan menggunakan interactive analysis models (Miles \& Huberman, 1984:12). Teknik analisis data dilakukan dengan 3 langkah atau alur, yaitu: 1) kegiatan pengumpulan data (data collection) yang sudah dilaksanakan yaitu melakukan pencatatan dan perekaman data; 2 ) kegiatan reduksi data (data 
reduction) dilakukan dengan mengklasifikasikan data sesuai dengan kelompoknya. Kegiatan reduksi data akan mempermudah menyimpulkan masalah dan melakukan pengumpulan data selanjutnya; 3) tahap penyajian data (display data). Manfaat yang diperoleh pada kegiatan ini adalah, peneliti lebih memahami proses perkembangan motorik kasar anak TK; 4) proses penarikan kesimpulan (conclusion: drawing/verification), hasil data di lapangan seringkali belum sesuai dengan kesimpulan yang dihasilkan.

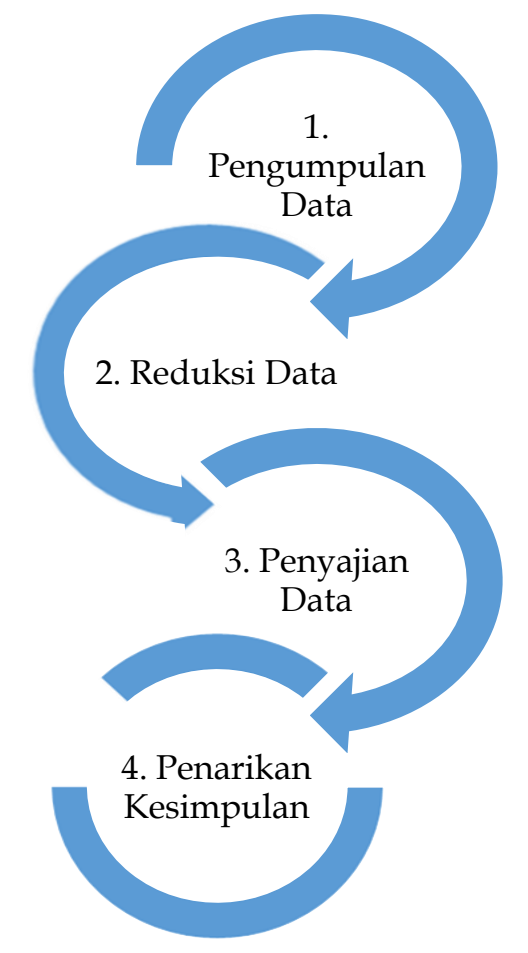

Gambar 1. Analisis Data Model (Milles \& Huberman, 1984)

\section{HASIL DAN PEMBAHASAN}

Perkembangan motorik merupakan salah satu faktor yang sangat penting. Untuk mengembangkan kemampuan motorik yaitu orang tua memberikan dukungan untuk mengasah motorik anak dengan memberikan kesempatan untuk dapat bereksplorasi dengan lingkungan sekitar rumah. Anak diberikan fasilitas atau sarana prasarana yang dapat mendorong anak untuk bergerak bebas. Karena saat ini orang tua membiarkan anak bermain tanpa dibatasi waktu. Hal itu menyebabkan anak menjadi duduk diam saja di rumah dengan menonton video sehingga berdampak pada kemampuan motorik anaknya mengalami keterlambatan.

Banyak faktor yang dapat mempengaruhi perkembangan motorik anak khususnya pada usia 0-6 tahun. Pada usia tersebut merupakan masa dimana anak senang bereksplorasi. Anak masih suka bermain, melakukan aktivitas gerak secara bebas tanpa berhenti. Faktor lingkungan sekitar rumah anak menjadi faktor yang berpengaruh besar terhadap motorik anak. Jika dilingkungan tempat tinggal banyak terdapat anak-anak dengan usia sebaya yaitu 3-6 tahun, maka akan lebih memilih untuk bermain di luar rumah dari pada hanya berdiam diri di dalam rumah. Keterampilan motorik anak juga perlu dilatih agar berkembang dengan bak. Untuk melakukan suatu aktivitas motorik, dibutuhkan ketersediaan energi yang cukup banyak. Setelah melakukan pengkajian tentang analisis pengembangan motorik kasar anak usia dini maka dapat dideskripsikan temuan sebagai berikut:

Temuan pertama, pengembangan motorik kasar anak membantu perkembangan kemampuan melompat satu kaki. Hal ini dikemukakan oleh Khoirunnisa Ainul (2020). Kemampuan melompat dengan satu kaki adalah salah satu bagian dari kemampuan motorik 
kasar pada anak. Melompat adalah bagian dari kemampuan motorik kasar yang sangat penting untuk dikembangkan dimana melompat menggunakan otot-otot besar, dimana otototot ini berguna untuk menggerakkan tubuh anak agar dapat berpindah dari satu tempat ke tempat yang lainnya. Pengembangan motorik kasar anak adalah kegiatan yang dilakukan dengan cara berjalan dan melompat dengan menggunakan satu kaki. Mengangkat satu kaki dan melompat menuju kotak demi kotak.

Temuan kedua, pengembangan motorik kasar anak mampu melatih koordinasi mata, tangan, dan kaki pada anak. Hal ini dikemukakan oleh Chadijah Siti (2015); Lindawati Desi Asnita (2013). Pengembangan motorik kasar adalah pengendalian gerakan yang terjadi melalui pusat syaraf, urat syaraf, dan gerakan otot-otot secara terkoordinasi. Motorik kasar adalah kemampuan anak untuk melakukan gerakan sebagian maupun seluruh tubuh dengan menggunakan otot-otot besar.

Temuan ketiga, pengembangan motorik kasar anak mampu melatih kelenturan, kecepatan, dan kelincahan pada anak. Hal ini dikemukakan oleh Maulana Kiki (2018); Adpriyadi (2017); Muslimah Ika (2018). Kelenturan, kecepatan, dan kelincahan adalah salah satu unsur dari gerakan motorik kasar pada anak. Ketika anak melompat dengan menggunakan satu kaki dan berpindah kekotak selanjutnya, dimana anak membutuhkan kecepatan, ketangkasan, dan kelincahan dalam bermain. Melalui gerakan-gerakan dalam pengembangan motorik kasar dimana anak berusaha untuk tetap terjaga agar tidak terjatuh, anak memiliki tumpuan sehingga anak dapat meloncat dengan tinggi, kemudian anak akan meloncat dengan cepat saat perpindahan tumpuan dan tolakan seolah-olah tidak ada jeda pada saat mendarat dan menolak.

Temuan keempat, pengembangan motorik kasar anak mampu meningkatkan keseimbangan tubuh anak. Hal ini dikemukakan oleh Pande Henny (2019); Yhana Pratiwi \& Kristanto (2015); Nasirun (2016). Keseimbangan adalah kemampuan seorang anak untuk dapat mempertahankan kondisi tubuhnya dalam segala posisi apapun. Menurut Decaprio dalam (Pande, Henny 2019), menyatakan keseimbangan adalah suatu kemampuan untuk mempertahankan gerakan, tingkah laku, sikap, dan konsentrasi otak pada saat melakukan praktek pembelajaran motorik. Keseimbangan tubuh anak akan berjalan dengan optimal apabila sejalan dengan perkembangan motorik kasar pada anak.

Temuan kelima, pengembangan motorik kasar mampu mengembangkan pertumbuhan fisik anak. Hal ini dikemukakan oleh Fitriani dan Saputa Rudy Yuli (2020); Salamah (2018); Salma Rozana (2019) Apriani Dian (2013). Perkembangan fisik adalah pengendalian gerakan tubuh yang merupakan pencapaian kematangan syaraf dan otot dimana secara umum kemampuan fisik motorik anak terbagi atas motorik halus dan motorik kasar Sanjaya dalam (Fitriani, 2020). Jadi, perkembangan fisik merupakan perkembangan semua bagian tubuh dan fungsinya, yang salah satunya adalah perkembangan motorik, berjalan, mengayun kaki kedepan dan kebelakang, dan berjalan sambil melompat. Selain gambaran hasil penelitian tersebut, maka analisis selanjutnya adalah sebagai berikut:

Analisis temuan pertama, pengembangan motorik kasar anak membantu perkembangan kemampuan melompat satu kaki. Temuan ini dikemukakan oleh Khoirunnisa Ainul (2020). Berdasarkan dari temuan ini, pengembangan motorik kasar anak membantu perkembangan yaitu: 1) kemampuan anak untuk melompat dengan satu kaki. 2) kemampuan anak untuk melompat dengan satu kaki ke depan. 3) kemampuan anak untuk melompat dengan satu kaki ke belakang. Kemampuan melompat merupakan salah satu gerakan dalam pengembangan motorik kasar pada anak dimana menggunakan otor-otot besar sehingga anak dapat berpindah tempat.

Analisis temuan kedua, pengembangan motorik kasar anak mampu melatih koordinasi mata, tangan, dan kaki pada anak. Hal ini disimpulkan dari pendapat yang dikemukakan oleh Chadijah Siti (2015), Lindawati Desi Asnita (2013). Berdasarkan dari temuan ini, bahwa pengembangan motorik kasar anak mampu melatih koordinasi otot-otot besar (mata, tangan, dan kaki) yaitu: 1) kemampuan anak untuk melakukan gerakan 
melompat. 2) kemampuan anak untuk berdiri sambil berjalan. 3) kemampuan anak untuk melompat sambil mengayun. Hal ini sejalan dengan pendapat Chadijah (2015), menyatakan bahwa motorik kasar adalah gerakan yang melibatkan sebagian maupun seluruh tubuh dengan menggunakan otot-otot besar (mata, tangan, dan kaki) secara terkoordinasi.

Analisis temuan ketiga, pengembangan motorik kasar anak mampu melatih kelenturan, kecepatan, dan kelincahan pada anak usia dini. Temuan ini dikemukakan oleh Maulana Kiki (2018), Adpriyadi (2017), dan Muslimah Ika (2018). Berdasarkan dari temuan ini, pengembangan motorik kasar anak mampu melatih kelenturan, kecepatan, dan kelincahan yaitu: 1) kemampuan anak untuk melompat dari satu kotak menuju kotak selanjutnya. 2) kemampuan anak untuk meloncat dengan cepat saat perpindahan tumpuan. 3) kemampuan anak untuk selalu tetap mempertahankan posisi tubuhnya. Kelenturan, kecepatan, dan kelincahan merupakan salah satu unsur gerakan dalam pengembangan motorik kasar pada anak usia dini.

Analisis temuan keempat, pengembangan motorik kasar anak membantu meningkatkan keseimbangan tubuh anak. Hal ini disimpulkan dari pendapat Pande Henny (2019), Yhana Pratiwi \& Kristanto (2015), Sundari \& Nasirun (2016). Hal ini didukung oleh teori yang dikemukakan Pande, Henny (2019) yang menyatakan bahwa keseimbangan tubuh adalah kemampuan mempertahankan gerakan, sikap, tingkah laku, dan konsentrasi otak pada saat melakukan praktek pengembangan motorik kasar. Dari temuan ini, melalui pengembangan motorik kasar anak mampu meningkatkan keseimbangan tubuh pada anak yaitu: 1) kemampuan anak berdiri dengan satu kaki secara seimbang. 2) kemampuan anak berdiri dengan dua kaki secara seimbang. 3) kemampuan anak untuk melompat dengan satu kaki secara seimbang. 4) kemampuan anak untuk melompat dengan dua kaki secara seimbang.

Analisis temuan kelima, pengembangan motorik kasar membantu pertumbuhan fisik pada anak usia dini. Temuan ini dikemukakan oleh Fitriani \& Saputra Rudy Yuli (2020), Salamah (2018), Salma Rozana (2019), dan Apriani Dian (2013). Temuan ini juga sejalan dengan pendapat Hurlock (2010:159), bahwa perkembangan motorik adalah perkembangan gerakan jasmani tubuh yang terjadi melalui kegiatan urat syaraf, pusat syaraf, dan otot-otot secara terkoordinasi.

\section{Pembahasan}

Pembahasan dengan temuan pertama, pengembangan motorik kasar anak usia dini membantu kemampuan melompat satu kaki. Hal ini dikemukakan oleh Khoirunnisa Ainul (2020). Kemampuan melompat dengan satu kaki adalah salah satu bagian dari pengembangan motorik kasar. Dalam gerakan-gerakan pengembangan motorik kasar anak adalah aktivitas gerakan melompat banyak terjadi. Melompat dengan satu kaki kedepan, kebelakang, melompat sambil berjalan, dan berdiri dengan dua kaki secara seimbang adalah pengembangan motorik kasar (melompat satu kaki).

Pembahasan dengan temuan kedua, pengembangan motorik kasar melatih koordinasi mata, tangan, dan kaki pada anak. Hal ini dikemukakan oleh Chadijah Siti (2015), Lindawati Desi Asnita (2013). Motorik kasar adalah kemampuan anak untuk melakukan gerakan sebagaian maupun seluruh tubuh dengan melibatkan otot-otot besar dan melalui pengembangan motorik kasar anak terjadi melalui gerakan melompat. Hal ini didukung dengan teori yang dikemukakan oleh (Kristanto 2015). Melompat merupakan salah satu pengembanagan motorik kasar karena menggunakan otot-otot besar yang melibatkan koordinasi mata, tangan, dan kaki.

Pembahasan dengan temuan ketiga, pengembangan motorik kasar melatih kelenturan, kecepatan, dan kelincahan pada anak. Pernyataan ini disimpulkan oleh Maulana kiki (2018); Adpriyadi (2017), dan Muslimah Ika (2018). Kelenturan, kecepatan, dan kelincahan merupakan unsur-unsur dari gerakan motorik kasar. Melalui gerakan-gerakan dalam 
pengembangan motorik kasar dimana anak akan berusaha mempertahankan posisinya agar tidak jatuh, pada saat melompat menuju kotak demi kotak anak akan membutuhkan kecepatan, dan anak akan melompat dengan cepat saat perpindahan tumpuan. Jadi, dapat disimpulkan bahwa melalui pengembangan motorik kasar anak usia dini dapat meningkatkan unsur-unsur kemampuan motorik kasar yaitu kelenturan, kecepatan, dan kelincahan.

Pembahasan dengan temuan keempat, pengembangan motorik kasar meningkatkan keseimbangan tubuh anak. Temuan ini dikemukakan oleh Pande Henny (2019); Yhana Pratiwi \& Kristanto (2015); Nasirun (2016). Keseimbangan adalah posisi anak untuk dapat mempertahanakan kondisi tubuhnya dalam segala posisi apapun (Nasirun 2016). Sementara menurut Pande Henny (2019) keseimbangan adalah kemampuan untuk mempertahankan gerakan, tingkah laku, sikap, dan konsentrasi otak pada saat melakukan praktek pembelajaran motorik. Keseimbangan tubuh merupakan salah satu kegiatan dari motorik kasar yang melibatkan koordinasi otot-otot besar yang dapat distimulasi dengan bermain lompat kodok, pernyataan dari teori Decaprio dalam (Nasirun 2016). Jadi, dapat disimpulkan bahwa keseimbangan tubuh anak akan berjalan dengan optimal apabila sejalan dengan perkembangan motorik kasar pada anak.

Pembahasan dengan temuan kelima, motorik kasar membantu pertumbuhan fisik anak. Pernyataan ini disimpulkan oleh Fitriani \& Saputra Rudy Yuli (2020); Salamah (2018); Salma Rozana (2019); dan Apriani Dian (2013). Perkembangan fisik adalah pengendalian gerakan tubuh yang merupakan pencapaian kematangan syaraf dan otot dimana secara umum kemampuan motorik anak terbagai atas motorik kasar dan motorik halus (Fitriani 2020). Hal ini juga sejalan dengan pendapat yang dikemukakan oleh (Salma Rozana 2019), menyatakan bahwa perkembangan motorik adalah perkembangan gerakan jasmani yang terjadi melalui kegiatan pusat syaraf, urat syaraf, dan otot secara terkoordinasi. Kegiatan bermain merupakan salah satu cara dalam menstimulasi aspek pengembangan motorik kasar. Melalui bermain akan banyak terjadi proses perkembangan dalam dirinya. Anak akan bergerak bebas, bereksplorasi, dan belajar dari apa yang dirasakan, dilihat, dan dialaminya yang akan menjadi sebuah pengalaman berharga bagi dirinya Piaget dalam (Maulana Kiki 2018). Perkembangan motorik berkaitan erat dengan pertumbuhan fisik. Hal ini didukung dengan teori yang dikemukakan oleh Elizabet Hurlock \& Heri dalam (Salma Rozana 2019).

\section{SIMPULAN}

Berdasarkan hasil analisis dan pembahasan, maka penelitian ini dapat disimpulkan bahwa pengembangan motorik kasar anak usia dini dapat: 1 . membantu pertumbuhan fisik pada anak, 2. meningkatkan keseimbangan tubuh anak, 3. melatih kelenturan, kecepatan, dan kelincahan, 4. melatih koordinasi mata, tangan, dan kaki, dan 5. membantu perkembangan kemampuan melompat dengan satu kaki.

\section{UCAPAN TERIMA KASIH}

Puji syukur kita panjatkan kepada Allah SWT atas rahmat dan karunia-Nya sehingga proses penerbitan Jurnal Obsesi: Jurnal Pendidikan Anak Usia Dini Volume x Issue x (xxxx) Pages $\mathrm{x}-\mathrm{xx}$ ini dapat berjalan dengan baik. Kemudian, ucapan terima kasih yang tak terhingga kami haturkan kepada penyunting pelaksana (Editors), dan penyunting ahli (Reviewers) yang tergabung ke dalam jurnal ini. Kami menyadari bahwa jurnal ini masih sangat mungkin terdapat kekurangan, kelemahan, ataupun keterbatasan. Oleh karena itu, saran dan masukan yang sifatnya membangun sangat diharapkan.

\section{DAFTAR PUSTAKA}

Ailwood, J. O. (2003). Governing Early Childhood Education through Play. Contemporary Issues in Early Childhood, 4(3), 286-299. https://doi.org/10.2304/ciec.2003.4.3.5 
Apriani, Dian. 2013. Penerapan Permainan Tradisional Engklek untuk Meningkatkan Kemampuan Motorik Kasar Anak Kelompok B RA AlHidayah 2 Tarik Sidoarjo Paud Teratai, Unesa, 2(1).

Apriyadi, A. 2017. Permainan Tradisional untuk Meningkatkan Kemampuan Motorik Kasar Kelompok B. Jurnal Pendidikan dan Pemberdayaan Masyarakat, 4 (2). https://doi.org/10.21831/jppm.v4i2.10016

Aye, T., Oo, K. S., Khin, M. T., Ahuja, T. K., \& Maruyama, H. (2017). Gross motor skill development of 5-year-old Kindergarten children in Myanmar. Journal of Physical Therapy Science, 29(10), 1772-1778. https:/ / doi.org/10.1589/jpts.29.1772

Chadijah, Siti. 2015. Peningkatan Kemampuan Motorik Kasar Melalui Permainan Engklek Pada Anak Usia 5-6 Tahun di TK Negeri Pembina. Jurnal Pendidikan dan Pembelajaran Khatulistiwa, 5 (3).

Erlinda, E, IW Dharmayana, and N Syam. 2014. Pengembangan Motorik Kasar Anak Usia Dini Melalui Permainan Melempar Dan Menangkap Bola. http:/ / repository.unib.ac.id/8663

Fitriani dan Saputra Rudy Yuli. 2020. Upaya Peningkatan Kemampuan Fisik Motorik Kasar Melalui Permainan Tradisional Engklek pada Kelompok B. Jurnal Pendidikan Anak Usia Dini, 1(2).

Hernandez, A. M., \& Cacola, a. P. (2015). Motor Proficiency Predicts Cognitive Ability in FourYear-Olds. European Early Childhood Education, 23(4), 37-41. https:// doi.org/10.1080/1350293X.2014.991094

Khairunnisa, Ainul. 2020. Pengaruh Permainan Engklek Modifikasi terhadap Kemampuan Motorik Kasar Anak Kelompok B TK Dharma Wanita. Jurnal Jurusan Bimbingan Konseling Undiskha.

Lindawati, Desi Anita. 2013. Pengaruh Permainan Tradisional Engklek Terhadap Kemampuan Motorik Kasar Lompat Satu Kaki di Kelompok A TK Pembina Srengat Blitar. Jurnal PAUD. 4 (2).

Maulana, Kiki. 2018. Peningkatan Kemampuan Motorik Kasar Anak melalui Permainan Tradisional Sunda Manda. Tarbiyah al-Aulad, 3(2).

Milles \& Huberman. (1984). Analisis Data Kualitatif. Jakarta: Universitas Indonesia Press.

Muslimah, Ika dkk. 2018. Permainan Engklek Dalam Meningkatkan Motorik Kasar Anak Usia 5-6 Tahun di RA Al Hikmah Kecamatan Medan Denai. Jurnal Raudhah 6(2).

Nasirun, M. 2016. Meningkatkan Motorik Kasar Melalui Permainan Tradisional Lompat Kodok. Jurnal Ilmiah Potensia, 1(1), 56-60.

Okely, A. D., Booth, M. L., \& Chey, \&. T. (2004). Relationships between Body Composition and Fundamental Movement Skills among Children and Adolescents. Research Quarterly for Exercise and Sport, 75(2), 238-247. https://doi.org/10.1080/02701367.2004.10609157

Olrich, T. W. (2013). Journal of Physical Education, Recreation \& Dance. Journal of Physical $\begin{array}{llll}\text { Education, } \quad \text { Recreation } \quad \text { Dance, 26-34. } & \end{array}$ https://doi.org/10.1080/07303084.2002.10607843

Pande, Henny. 2019. Pengaruh Permainan Tradisional Engklek Deprok Terhadap Perkembangan Keseimbangan Anak Didik. Prosiding Seminar Nasional Fakultas Ilmu Pendidikan. 3(2019).

Patiung, D., Ismawati, I., Herawati, H., \& Ramadani, S. (2019). Deteksi dini pencapaian perkembangan anak usia 3-4 tahun berdasarkan Standar Nasional Pendidikan Anak Usia Dini. Indonesian Journal of Early Childhood Education, 2(1), 25-38. https://doi.org/10.24252/nananeke.v2i1.9223

Permendikbud No. 137. (2014). Standar Nasional Pendidikan Anak Usia Dini. Jakarta: Menteri Hukum dan Hak Asasi Manusia. 
Piek, J. P., Dawson, L., Smith, L. M., \& Gasson, N. (2008). The Role of Early Fine and Gross Motor Development on Later Motor and Cognitive Ability. Human Movement Science, 27(5), 668-681. https:/ / doi.org/10.1016/j.humov.2007.11.002

Pratiwi, Yhana \& Kristanto. 2015. Upaya Meningkatkan Kemampuan Motorik Kasar (Keseimbang Tubuh) Anak Melalui Permainan Tradisional Engklek Kelompok B. Jurnal Penelitian dalam Bidang Pendidikan Anak Usia Dini. 3 (2).

Robinson, L. E., Webster, E. K., Logan, S. W., Lucas, W. A., \& Barber, L. T. (2012). Teaching Practices that Promote Motor Skills in Early Childhood Settings. Early Childhood Education Journal, 40(2), 79-86. https:// doi.org/10.1007/s10643-011-0496-3

Rozana, Salma. 2019. Peningkatan Motorik Kasar Anak Melalui Permainan Engklek di PAUD Al-Ashry Kel.Pekan Selesai Kec.Langkat. Jurnal Abdi Ilmu, 12(2), 132-142).

Salamah, Miftahillah. 2018. Pengaruh Permainan Tradisional Engklek terhadap Perkembangan Fisik Motorik Kasar Anak Usia Dini Usia 4-5 Tahun di TK Ar-Rieza Dua Beji Pasuruan. PROCEEDING: The Annual International conference on Islamic Education 3(2), 165-177.

Susanto, Ahmad. (2010). Perkembangan Anak Usia Dini Pengantar dalam Berbagai Aspeknya. Jakarta: Kencana.

Suyadi, Aghnaita. (2013). Konsep Dasar PAUD. Bandung: PT Remaja Rosdakarya, 2013.

Tandon, P., Hassairi, N., Soderberg, J., \& Joseph, G. (2020). The relationship of gross motor and physical activity environments in child care settings with early learning outcomes. Early Child Development and Care, 190(4), 570-579. https:// doi.org/10.1080/03004430.2018.1485670

Temple, V. A., Crane, J. R., Brown, A., Williams, B. L., \& Bell, R. I. (2016). Recreational activities and motor skills of children in kindergarten. Physical Education and Sport Pedagogy, 21(3), 268-280. https://doi.org/10.1080/17408989.2014.924494

Theobald, M., Danby, S., Einarsdottir, J., \& Bourne, J. (2015). Children's Perspectives of Play and Learning for Educational Practice. Education Sciences, 5(4), 345-362. https:// doi.org/10.3390/educsci5040345

Undang-Undang No. 20. (2003). Sistem Pendidikan Nasional. Jakarta: Media Wacana.

Wainwright, N., Goodway, J., John, A., Thomas, K., Piper, K., Williams, K., \& Gardener, D. (2020). Developing children's motor skills in the Foundation Phase in Wales to support physical literacy. Education 3-13, 48(5), 565-579. https:/ / doi.org/10.1080/03004279.2019.1633374

Williams, H. G., Pfeiffer, K. A., O'Neill, J. R., Dowda, M., McIver, K. L., Brown, W. H., \& Pate, R. R. (2008). Motor skill performance and physical activity in preschool children. Obesity, 16(6), 1421-1426. https://doi.org/10.1038/oby.2008.214

Zhang, L., Sun, J., Richards, B., Davidson, K., \& Rao, N. (2018). Motor Skills and Executive Function Contribute to Early Achievement in East Asia and the Pacific. Early Education and Development, 29(8), 1061-1080. https://doi.org/10.1080/10409289.2018.1510204 